$\begin{array}{cl}\text { Türkiye Tarımsal Araştırmalar Dergisi } & \text { Turk J Agric Res } \\ \text { http://dergi.siirt.edu.tr } & \text { (2016) 3: 48-54 } \\ \text { OTÜTAD } & \text { ISS: 2148-2306 } \\ \text { Aoi: 10.19159/tutad.73648 }\end{array}$

\title{
Yumurta İçi (In Ovo) Propolis Enjeksiyonunun ve Enjeksiyon Yerinin Kuluçka Randımanı, Civciv Çıkış Ağırlığı ve Yaşama Gücüne Etkileri
}

\author{
Canan KOP BOZBAY ${ }^{1 *}$, Kalbiye KONANÇ ${ }^{2}$, Nuh OCAK $^{1}$, Ergin ÖZTÜRK $^{1}$ \\ ${ }^{1}$ Ondokuz Mayıs Üniversitesi, Ziraat Fakültesi, Zootekni Bölümü, Samsun, TÜRKIYYE \\ ${ }^{2}$ Ordu Üniversitesi, Ulubey Meslek Yüksekokulu, Veterinerlik Bölümü, Ordu, TÜRKIYYE
}

\begin{abstract}
Geliș Tarihi/Received: 10.12 .2015
Kabul Tarihi/Accepted: 29.02.2016

*Sorumlu yazar/Corresponding author: canankop@gmail.com

Özet: Bu çalıșmada, yavaş gelișen iki farklı etlik piliç hattında yumurta içi (in ovo) propolis enjeksiyonunun ve enjeksiyon yerinin kuluçka randımanı, çıkış ağırlığı ve yaşama gücü üzerine etkilerini değerlendirmek amacı ile iki deneme yürütülmüștür. Deneme 1'de Ross x (Ross x Rhode Island Red) melezi etlik piliç anaçlarından (30 haftalık yaşta) elde edilen 70 adet döllü yumurta, 2 (tuz ve propolis solusyonu) $\times 2$ (hava kesesi ve amniyotik sıvı) faktöriyel dizaynda 4 grubuna dağıtılmıştır. Deneme 2'de Ross x Barred Plymouth Rock melezi etlik piliç anaçlarından (32 haftalık yaşta) elde edilen 64 adet döllü yumurta 3 gruba tesadüfî olarak dağıtılmıştır. Deneme 1'de inkübasyonun 19. gününde $0.5 \mathrm{ml} \% 0.9$ tuz veya \% 4.6 propolis solüsyonları, yumurtanın hava kesesi veya amniyotik sıvısına, Deneme 2 'de ise inkübasyonun 18 . gününde 0.5 $\mathrm{ml} \% 0.9$ tuz solüsyonu yumurtanın hava kesesi veya amniyotik sıvısına küt ve sivri ucundan enjekte edilmiștir. Her iki denemede de in ovo propolis enjeksiyonu ve enjeksiyon yeri kuluçka randımanı, çıkış ağırlı̆̆ı ve yaşama gücünü etkilememistir. Bununla birlikte, 1. denemede kuluçka randımanı ve çıkıs ağırlığı in ovo enjeksiyon bölgesine sırasıyla bağımlı $\left(\chi^{2}=8.020, \mathrm{P}<0.01\right)$ ve bağımlı olma eğiliminde $(\mathrm{P}<0.10)$ olmuştur. Sonuçta, hava kesesine in ovo propolis uygulamasının çıkış randımanını artıımasına rağmen, civciv ağırlığını düşürme eğiliminde olduğu söylenebilir.
\end{abstract}

Anahtar Kelimeler: Kümes hayvanları, propolis, yumurta içi besleme, enjeksiyon bölgesi, civciv çıkış özellikleri

\section{The Effects of In Ovo Injection of Propolis and Injection Site on Hatchability, Hatching Weight and Survival of Chicks}

\begin{abstract}
In this study, two experiments were conducted to evaluate the effects of in ovo injection of propolis and injection sites in ovo on hatchability, hatching weight and survival of newly-hatched chicks in two different lines of slow-growing broiler. In Experiment 1, 70 fertile eggs from Ross x Rhode Island Red breeder (30-week-old) were allocated to four groups according to a 2 (saline and propolis solution) $\times 2$ (air cell and amniotic fluid) factorial arrangement. In Experiment 2, 64 fertile eggs from Ross x Barred Plymouth Rock breeder (32-week-old) were allocated randomly to three groups. In Experiment 1, a $0.5 \mathrm{ml}$ of $0.9 \%$ saline or $4.6 \%$ propolis solution was administered to the air cell or the amniotic fluid of eggs at day 19 of incubation. In Experiment 2, at $18 \mathrm{~d}$ of incubation $0.5 \mathrm{ml}$ of $0.9 \%$ saline solution was administered to the air cell or the amnion at the blunt end and the pointed end of the egg. In the both experiments, the hatchability, hatching weight and survival of newly-hatched chicks were not affected by in ovo injection of propolis and injection sites. However, in Experiment 1 , while the hatchability $\left(\chi^{2}=8.020, \mathrm{P}<0.01\right)$ was dependent on the injection sites, hatching weight of newlyhatched chicks $(\mathrm{P}<0.10)$ was tend to be dependent on the injection sites. In conclusion, it can said that in ovo administration of propolis to the air cell increased the hatchability, but was tended to reduce the hatching weight of chicks.
\end{abstract}

Keywords: Poultry, propolis, in ovo feeding, injection site, chick hatching traits 


\section{Giriş}

Ticari kümes hayvancılığında kuluçkahanedeki verimlilik ve üretime başlangıç, maksimum kar elde etmedeki önemli faktörlerdir. Civcivler, yumurtadan yaklaşık 36-48 saatlik bir zaman diliminde çıkarlar ve genellikle \% 95 çıkış oranına ulaşıldığında kuluçka işlemi bitirilir. Bu zaman dilimine kuluçka uygulamaları (sağlık kontrolü, cinsiyet ayırımı vb.) ve yetiştirme kümeslerine nakil işlemlerinin süreleri de eklendiğinde, civcivler, yem ve sudan yaklaşı 48-72 saat boyunca yoksun kalabilirler. $\mathrm{Bu}$ kadar uzun süre aç ve susuz kalan hayvanların besi başlangıç ağırlığı, gelişimi ve final ağırlıkları, ilgili genotipin veya hattın normal değerlerinin altında kalmaktadır. Bu durum, kanatlılarda erken dönem beslenme stratejilerinin geliştirilebilmesi için yapılan araştırmaların artmasına neden olmuştur. $\mathrm{Bu}$ araştırmalar sonucunda yumurta içi (in ovo) besleme konusu gündeme gelmiş ve bu konudaki araştırmalar yoğunluk kazanmıştır. Yumurta içi beslemenin, çıkış sonrası hastalık ve ölüm oranlarının azaltılması, hayvanlarda sindirim kapasitesinin iyileştirilmesi, büyüme hızı ve yemden yararlanma etkinliğinin arttırılması, enterik hastalıklara karşı bağ 1 şıklık sisteminin geliştirilmesi, gelişimsel iskelet bozuklukları yoğunluğunun azaltılması, kas gelişimi ve göğüs eti veriminin arttırılması amac1 ile yapılması gerektiği ileri sürülmektedir (Bhanja ve ark., 2004; Uni ve ark., 2005). Bu amaçla, etlik piliç üretiminde, glikoz, amino asit, iz mineral, esansiyel yă asitleri ve vitamin gibi besin maddelerinin in ovo enjeksiyonu ile ilgili yoğun araştırmalar yapılmaktadır (Ohta ve ark., 1999, 2001; Ohta ve Kidd, 2001; Bhanja ve ark., 2004, 2008; Bakyaraj ve ark., 2012).

Kanatlı hayvan üretiminde verimi etkileyen en önemli unsurların başında civciv çıkış özellikleri (civciv çıkış oranı ve çıkış ağırlığı) gelmektedir. İn ovo beslemenin civciv çıkış özellikleri üzerine hem enjeksiyonda kullanılan maddeden, hem de enjeksiyon yeri ve bölgesinden kaynaklanan önemli etkileri bulunmaktadır. Civciv çıkış özelliklerinin arttırılmasına yönelik yapılan in ovo besleme çalışmalarında, enjeksiyon genellikle hava kesesine yapılmasına rağmen, uygun enjeksiyon yeri bakımından farklı önerilerde bulunulmaktadır. Nitekim, bazı çalışmalarda (Ohta ve Kidd, 2001; Ohta ve ark., 2001) en uygun in ovo enjeksiyon yerinin yolk kesesi ya da ekstra-embriyonik boşluk olduğu, bazı çalışmalarda (Uni ve Ferket, 2003, 2004) ise amniyotik sıvı olduğu bildirilmektedir. Bununla birlikte, yumurtanın hangi bölgesinden amniyotik sıvıya enjeksiyon yapılması ile ilgili yeterli bilgi bulunmamaktadır.
Son yıllarda arı ürünlerinin de in ovo besleme çalışmalarında değerlendirildiği görülmektedir. Nitekim arı sütünün etlik piliç damızlık yumurtalarına in ovo enjeksiyonunun civciv çıkış özelliklerini olumlu etkilediği belirlenmiştir (Moghaddam ve ark., 2013, 2014). Arıların bitkilerden ürettiği ve kovan içi temizlikte ve kovanın yalıtımında kullandıkları reçinemsi veya mum benzeri bir madde olan propolisin, antibakteriyel ve antifungal aktiviteleri olduğu bilinmektedir. Propolisin antibiyotik ve bağışıklığ uyarıcı (immuno-stimulating) gibi özellikleri yanında geniş spektrumlu bir etkiye sahip olduğu (Dimov ve ark., 1991; Sforcin ve ark., 2000) ve dolayısıyla kanatlı diyetlerinde antibiyotiklere alternatif doğal yem katkı maddesi olarak kullanılabileceği ileri sürülmektedir (Denli ve ark., 2005). Bu özelliklerinden dolayı propolisin in ovo enjeksiyonu, çıkış gücü (kuluçka randımanı), çıkış ağırlığı ve yaşama gücünü arttırmak için alternatif bir kaynak olarak değerlendirilebilir.

In ovo beslemede kullanılan maddeler ve in ovo enjeksiyon bölgesi, yavaş gelişen etlik piliç damızlıklarında da civciv çıkış gücü ve ağırlığı gibi çıkış özelliklerini ve sonuçta, elde edilecek verimliliği etkileyebilir. Bununla birlikte, yavaş gelişen etlik piliç üretiminde bağışıklık sistemini arttırmak için damızlık yumurtalara in ovo propolis enjeksiyonu ve enjeksiyon bölgesi ile ilgili yayınlanmış araştırma bulunmamaktadır. Dolayısıyla, bu çalışma, yavaş gelişen iki farklı etlik piliç hattından (Ross x Rhode Island Red, RIR ve Ross x Barred Plymouth Rock, BAR) elde edilen damızlık yumurtalara in ovo propolis enjeksiyonunun ve enjeksiyon yerinin kuluçka randımanı, çıkış ağırlığı ve yaşama gücü üzerine etkilerini değerlendirmek amacı ile yapılmıştır.

\section{Materyal ve Yöntem}

Ondokuz Mayıs Üniversitesi, Ziraat Fakültesi, Araştırma ve Uygulama Çiftliği Hayvancılık Birimi Kanatlı Ünitesi'nde yürütülen bu araştırmada, iki farklı deneme yapılmıştır. Denemelerde kullanılan yumurtalar, yavaş gelişen bir hat olarak geliştirilen sırasıyla 30 ve 32 haftalık yaştaki RIR ve BAR melezlerinin (Boz ve ark., 2014; Yamak ve ark., 2014) etlik piliç anaçlarından elde edilmiştir. Her iki denemede de yumurtalar Boz ve ark. (2014) ve Yamak ve ark. (2015) tarafindan açıklandığ 1 şekilde kuluçka işlemlerine tabi tutulmuştur.

\subsection{Deneme 1}

Deneme 1'de, kuluçkanın 18. günü 12. saatinde olan toplam 70 adet döllü yumurta kullanılmıştır. Yumurtaların döllülük kontrolleri, bu amaca 
yönelik olarak özel yaptırılmış aydınlatma ünitesinde yapılmıştır. Yumurtalar, iç aydınlatma düzeneği üzerinde iken, hava keseleri ve embriyonun bulunduğu bölge işaretlenmiştir. Yumurtalar, ağırlıkları birbirine yakın olacak şekilde 2 (tuz ve propolis solusyonu) $\mathrm{x} 2$ (amniyotik sıvı ve hava kesesi) faktöriyel düzende 4 muamele grubuna ayrılmıştır. Daha sonra, $0.5 \mathrm{ml}$ \% 0.9 'luk tuz (4.5 mg/yumurta) veya \% 4.6 'lik propolis (23 $\mu \mathrm{g} /$ yumurta) solüsyonları yumurtanın amniyotik sıvısına veya hava kesesine $19 \mathrm{~mm}$ ve 27-ga'lık iğne ile enjekte edilmiştir.

Denemede kullanilan propolis, denemenin yürütüldüğü hayvancılık biriminin arıcılık ünitesinden elde edilmiştir. Propolis solüsyonu, ham propolisin \% 70'lik etanol ile ekstrakte edilmesi ile hazırlanmıştır (Shalmany ve Shivazard, 2006; Arslan ve ark., 2010). Propolis solüsyonundan $460 \mu \mathrm{l}$ propolis ekstraktı $540 \mu \mathrm{l}$ $\%$ 0.9'luk steril serum fizyolojik sıviyla $1 \mathrm{ml}$ 'ye tamamlanmış, $47 \mathrm{~mm}$ çaplı $0.2 \mu \mathrm{m}$ porlara sahip dairesel şekilli filtrelerden geçirilerek steril hale getirilmiştir (Velazquez ve ark., 2007; Zhai ve ark., 2011). Serum fizyolojikte hazırlanan propolis solüsyonunun sicaklığının embriyonun vücut sıcaklığına eşit olması için, solüsyon, in ovo işlem süresince $37{ }^{\circ} \mathrm{C}$ 'de 1sitilan su banyosunda bekletilmiştir (Arslan ve ark., 2010).

\subsection{Deneme 2}

Bu denemede kuluçkanın 19. günü 12. saatinde olan toplam 64 adet döllü yumurta kullanılmıştır. Eşit ağırlıktaki döllü yumurtalara $0.5 \mathrm{ml} \% 0.9$ tuz solüsyonu yumurtanın hava kesesine ve yumurtanın küt veya sivri ucundan amniyotik sıvıya yukarıda açıklanan metot ve miktarda enjekte edilmiştir.

$\mathrm{Bu}$ tür çalışmalarda pozitif (delinmemiş yumurta) ve negatif (delinmiş ve serum fizyolojik enjekte edilmiş yumurta) olmak üzere iki kontrol grubu oluşturulmaktadır. Ancak gerek embriyo ağırlığı ve gerekse çıkışta palaz veya civcivlere ait özellikler bakımından her iki kontrol grubu arasında istatistiki olarak farklılıkların olmadığı bildirilmektedir (Uni ve ark., 2005; Dos Santos ve ark., 2010; Liu ve ark., 2012; Gonzales ve ark., 2013). Dolayısıyla, her iki denemede de sadece negatif kontrol grubu denemeye dâhil edilmiştir. Her iki denemede de yumurtalarda oluşan iğne delikleri embriyoya kontaminasyonları önlemek amaciyla $37{ }^{\circ} \mathrm{C}$ su banyosunda bekletilen sıv1 parafin ile kapatılmış ve tüm yumurtalar çıkış ünitesine alınmıştır. Çıkıştan sonra kuluçka randımanı, civciv ağırlığı ve bir hafta süresince genç civcivlerin varsa ölümleri kaydedilmiştir.

Deneme 1'de civciv çıkış ağırlığına ait veriler, tesadüf parselleri deneme deseninde $2 \times 2$ faktöriyel dizaynda ( 2 solüsyon $\times 2$ enjeksiyon yeri) iki yönlü (solüsyonun, enjeksiyon yerinin ve bunlar arasındaki interaksiyonun etkileri) ve Deneme 2'den elde edilen veriler ise ayn deneme deseninde tek yönlü varyans analizine tabi tutulmuş ve ortalamalar arasındaki farklılık Duncan çoklu karşılaştırma testi ile belirlenmiştir. Her iki denemedeki, çıkış randımanı ve yaşama gücüne ait veriler, Chi kare $\left(\chi^{2}\right)$ testi ile analiz edilmiştir. İstatistiki analizler, IBM SPSS Statistics version $21.0 \quad$ (Anonymous, 2013) paket programının sirasiyla General Linear Model, Compare Means ve Nonparametric Test işlemleri kullanılarak yapılmıştır.

\section{Bulgular ve Tartışma}

Tuz ve propolis solusyonlarının yumurtanın hava kesesi ve amniyotik sivisına in ovo enjeksiyonunun etkileri Tablo 1'de gösterilmiştir. Tuz solüsyonunun hava kesesi ve yumurtanın küt ve sivri ucundan amniyotik sıviya enjeksiyonun etkileri ise Tablo 2'de sunulmuştur. Bu çalışmanın her iki denemesinde de in ovo enjeksiyon ve enjeksiyon yerleri kuluçka randımanını, civcivlerin çıkış ağırlığını ve yaşama gücünü etkilememiştir (Tablo 1 ve Tablo 2). Bununla birlikte, Deneme 1 'de, kuluçka randımanı ve civciv çıkış ağırlığı üzerine solüsyon $\mathrm{x}$ enjeksiyon yeri interaksiyonun etkisi önemli bulunduğundan, bu özellikler sırasıla in ovo enjeksiyon bölgesine bağıml $\left(\chi^{2}=8.020, \mathrm{P}<0.01\right)$ ve bağıml olma $(\mathrm{P}<0.10)$ eğiliminde olmuştur (Şekil 1 ve Şekil 2).

Tablo 1. Tuz ve propolis solüsyonlarının in ovo enjeksiyonunun ve enjeksiyonun yerinin civciv çıkış randımanı, çıkış ağırlığı ve bir haftalık yaştaki yaşama gücü üzerine etkileri

\begin{tabular}{lccccccc}
\hline & \multicolumn{2}{c}{ Solüsyon } & \multicolumn{3}{c}{ Enjeksiyon yeri } & \\
\cline { 2 - 6 } & $\begin{array}{c}\text { Tuz } \\
(\mathrm{n}=21)\end{array}$ & $\begin{array}{c}\text { Propolis } \\
(\mathrm{n}=49)\end{array}$ & $\chi^{2}$ & $\begin{array}{c}\text { Hava kesesi } \\
(\mathrm{n}=28)\end{array}$ & $\begin{array}{c}\text { Amniyotik sıv1 } \\
(\mathrm{n}=32)\end{array}$ & $\chi^{2}$ & OSH \\
\hline Çıkış randımanı, \% & 81.25 & 89.47 & 0.376 & 90.24 & 79.31 & 0.716 & \\
Çıkış ağırlığı, g/civciv & 43.90 & 45.12 & & 44.59 & 44.59 & & 0.495 \\
Yaşama gücü, \% & 86.80 & 81.25 & 0.214 & 90.24 & 75.86 & 1.181 & \\
\hline
\end{tabular}

OSH: Ortalamanın standart hatası 
Tablo 2. Tuz solüsyonunun hava kesesi ve yumurtanın küt ve sivri ucundan amniyotik siviya in ovo enjeksiyonunun civciv çıkış randımanı, çıkış ağırlığı ve bir haftalık yaştaki yaşama gücü üzerine etkileri

\begin{tabular}{|c|c|c|c|c|c|}
\hline & \multirow[b]{2}{*}{$\begin{array}{l}\text { Hava kesesi } \\
\quad(\mathrm{n}=21)\end{array}$} & \multicolumn{2}{|c|}{ Amniyotik s1v1 } & \multirow[b]{2}{*}{$\chi^{2}$} & \multirow[b]{2}{*}{$\mathrm{OSH}$} \\
\hline & & $\begin{array}{l}\text { Küt uç } \\
(\mathrm{n}=23)\end{array}$ & $\begin{array}{c}\text { Sivri uç } \\
(\mathrm{n}=20)\end{array}$ & & \\
\hline Yumurta ağırlığı (YA), g & 55.38 & 55.57 & 56.86 & 0.748 & 0.748 \\
\hline Çıkış randımanı, \% & 95.24 & 100.00 & 90.00 & 0.526 & \\
\hline Civciv çıkış ağırlığı (CÇA), g & 45.63 & 45.74 & 45.31 & & 0.449 \\
\hline CÇA/YA & 80.24 & 82.88 & 81.54 & & 1.260 \\
\hline Yaşama gücü, \% & 95.24 & 100.00 & 90.00 & 0.526 & \\
\hline
\end{tabular}

OSH: Ortalamanın standart hatası

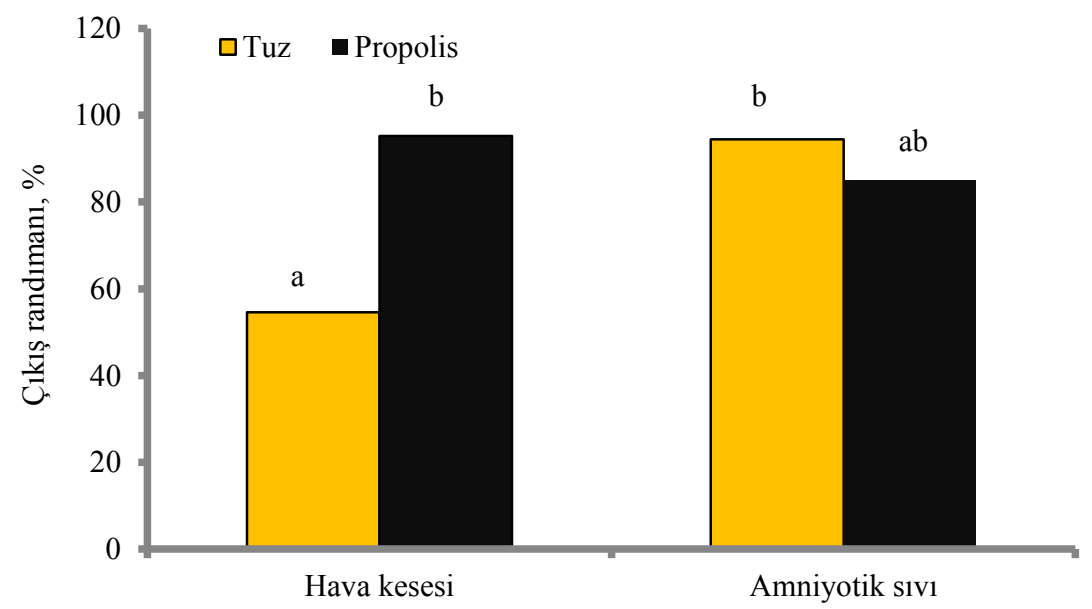

Şekil 1. Tuz ve propolis solüsyonlarının yumurtanın hava kesesi ve amniyotik sıvısına in ovo enjeksiyonunun çıkış randımanı üzerine etkileri a, b: Farklı harfle gösterilen barlar istatistiki olarak farklıdır $\left(\chi^{2}=8.020, \mathrm{P}<0.01\right)$.

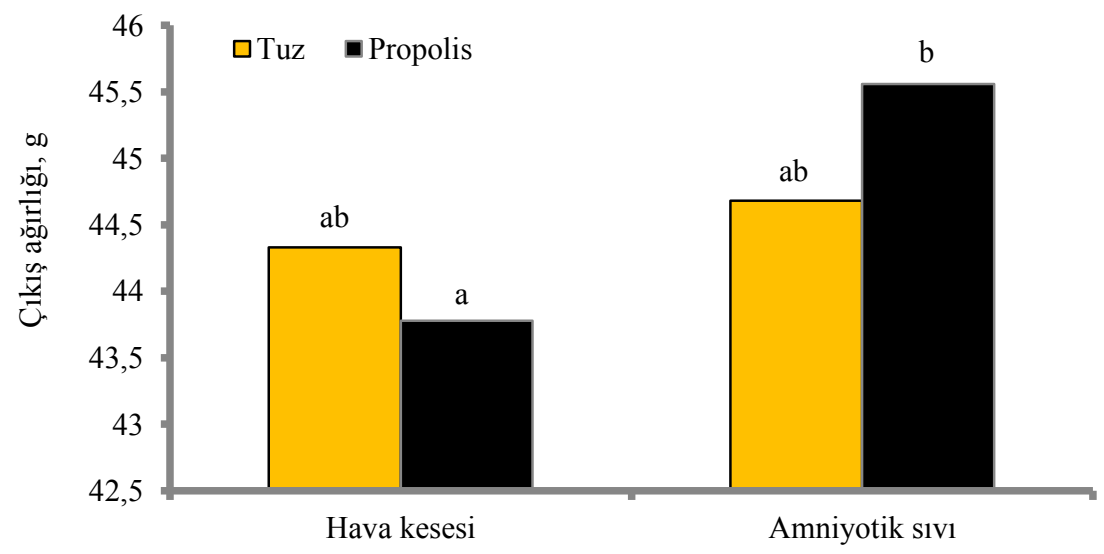

Şekil 2. Tuz ve propolis solüsyonlarının yumurtanın hava kesesi ve amniyotik sıvısına in ovo enjeksiyonunun civciv çıkış ağırlığı üzerine etkileri a, b: Farklı harfle gösterilen barlar istatistiki olarak farklıdır $(\mathrm{P}<0.10)$.

Mevcut çalışmanın sonuçları, hava kesesine in ovo propolis uygulamasının çıkış randımanı arttırabileceğini, ancak civciv çıkış ağırlığında bir düşüşe neden olabileceğini ortaya koymuştur. Bununla birlikte, çıkış randımanı ile ilgili sonuçlar, hem RIR hattının (Boz ve ark., 2014), hem de BAR (Yamak ve ark., 2015) hattının deneysel anaçlarından elde edilen değerler arasında bulunmuştur. Nitekim Boz ve ark. (2014) RIR ve BAR hatları için ortalama çıkış randımanlarının 
sirasıyla \% 87.9 ve \% 89.0, Yamak ve ark. (2015) ise $\% 89.2$ ve $\% 86.9$ olduğunu bildirmişlerdir. Mevcut denemeden ve diğer çalışmalardan (Uni ve ark., 2005; Dos Santos ve ark., 2010) elde edilen sonuçlar, yumurtaların in ovo enjeksiyon amacı ile delinmesinin çıkış randımanını etkilemediğini göstermektedir. Bu sonuçlar, çıkışta palaz veya civcivlere ait özellikler bakımından delinen ve delinmeyen yumurta grupları arasında istatistiki bakımdan farklılıkların olmadığını bildiren çalışma sonuçları (Uni ve ark., 2005; Dos Santos ve ark., 2010; Liu ve ark., 2012; Gonzales ve ark., 2013) ile uyum içerisindedir.

Embriyo ve çıkışta civcivlerin karaciğerinde enterik gelişme ve vücut rezervlerinin durumu ile in ovo besleme arasında pozitif bir etkileşim olduğu bildirilmiştir (Uni ve ark., 2003). Dolayısıyla, civciv çıkış oranını, yaşama gücünü ve verimliliğini iyileştiren fizyolojik veya besinsel şartları manipule edecek etkin yollardan birisi de spesifik besin ve bağışıklık sistemini geliştirici maddeler ile in ovo besleme uygulamalarıdır (Ohta ve ark., 2001; Ohta ve Kidd, 2001; Bhanja ve ark., 2008; Bakyaraj ve ark., 2012). Bu bilgiler, mevcut çalışmada propolisin neden civciv çıkış randımanını artırma eğiliminde olduğunu açıklayabilir.

Mevcut çalışmadaki çıkış gücü ile ilgili sonuçlar, hava boşluğu ya da koriyoallantoyik zara yapılan in ovo enjeksiyonun etlik piliçlerde civciv çıkış oranını olumsuz etkilediğini gösteren çalışma sonuçları (Moghaddam ve ark., 2013, 2014) ile aynı doğrultudadır. Bununla birlikte Deneme 1'de çıkış randımanının hava kesine yapılan enjeksiyonda amniyotik sıvıya göre yaklaşık 11 puan daha yüksek olması, enjeksiyon bölgesi olarak hava kesesinin daha uygun olduğunu gösterir. Propolisin etkisinin aksine, in ovo arı sütü uygulaması (Moghaddam ve ark., 2013, 2014), etlik piliçlerde çıkış oranını düşürmüş ve çıkış ağırlığını arttırmıştır. In ovo besleme uygulamalarında civciv çıkış gücünün düşmesi, uygulama hatasından ve özellikle düşük kaliteli embriyoların dışarıdan gelen besin maddelerine yeterli adaptasyon gösterememesinden kaynaklanabilir. Gerçekten de, in ovo besleme sonrası embriyoda bir takım fizyolojik ve metabolik değişikliklerin meydana geldiği (Christensen ve ark., 2001; Moran, 2007) ve bu aşamadaki herhangi bir aksaklığın embriyonun ve yeni çıkmış civcivin yaşama gücünü olumsuz etkilediği belirlenmiştir (Collin ve ark., 2007; Leksrisompong ve ark., 2007). Çıkış öncesi dönemdeki en önemli fizyolojik ve metabolik işlemlerden ilki glikoz homeostasisinin korunması, ikinci ise inkübasyonun sonuna doğru, sindirim sisteminde yoğun morfolojik, hücresel ve moleküler değişimlerin meydana gelmesidir (Foye ve ark., 2007). Nitekim, etlik piliçlerde inkübasyonun son gününe doğru bağırsak ağırlığının embriyonik ağırlığa oranının \% 1.4 , çıkışta ise \% 3.4'e yükseldiği belirlenmiştir (Uni ve ark., 2002). Bu nedenle, embriyonun amniyotik sıvısına arı sütü (Moghaddam ve ark., 2013, 2014) ve propolis gibi embriyonun beslenmesini ve bağışıklık sistemini uyarıcı maddelerin enjeksiyonu, embriyonun bağırsaklarına bu tür maddelerin çıkış öncesi ulaşmasını sağlamış (De Oliveira ve ark., 2008) ve bu embriyolarda meydana gelen fizyolojik ve metabolik değişikliklere adaptasyonu düşük olan civcivlerin kabuk altı ölümlerine neden olmuş olabilir.

Çıkış oranı ve civciv ağırlığını geliştirmek amacı ile yapılan bazı çalışmalar (Ohta ve Kidd, 2001; Ohta ve ark., 2001), bir amino asit solüsyonunun (yumurta akı amino asit profiline benzer) in ovo enjeksiyonu için en uygun enjeksiyon yerinin yumurta sarı kesesi veya ekstraembriyonik boşluk olduğu bildirilmiştir. Araştırıcılar (Ohta ve ark., 2001; Ohta ve Kidd, 2001; Moghaddam ve ark., 2013, 2014) bu durumu, yüksek çıkış ağırlığı sahip civcivlerin dokularındaki amino asit konsantrasyonun da daha yüksek olmasına bağlamışlardır. Dolayısıyla, amniyotik sıvıya propolis enjeksiyonunun (enjeksiyon yerine bağlı olmaksızın) çıkış randımanını arttırmasına rağmen, civciv ağırlığını düşürme eğiliminde olması, çıkış öncesi bağırsaklarda meydana gelen fizyolojik değişimler ile bu hayvanların bağışıklık sisteminin daha fazla gelişmiş olmasıyla (Foye ve ark., 2007) açıklanabilir.

Sindirim sisteminin fonksiyonel kapasitesine daha erken ulaşması, civcivin çıkış sonrası enfeksiyöz ve metabolik hastalıklara daha etkin şekilde karşı koymasına, aldığ 1 besin maddelerini daha hızlı kullanmasına ve sonuçta enerji durumunu daha etkin şekilde koruyabilmesine neden olmaktadır (Uni ve ark., 2002; Bigot ve ark., 2003). Mevcut çalışmanın sonuçları, gruplar arasında yaşama gücü bakımından farklılık bulunmadığından, bu bilgileri desteklememiştir. Literatürde propolisin in ovo enjeksiyonu ile ilgili araştırma olmamasına rağmen, propolisin bağışıklığı uyarıcı etkisine (Dimov ve ark., 1991; Sforcin ve ark., 2000) benzer bir özellik gösteren $\mathrm{CpG}$

(Sitozin-fosfo-Guanin) oligodeoksinukleotidlerin in ovo enjeksiyonunun kanatlılarda koksidiosise karşı bağışıklılı̆̆ arttırdığı bildirilmiştir (Tewari ve Maharana, 2011). Propolisin civciv çıkış ağırlığını nispeten düşürme eğiliminde olmasına rağmen, civcivlerin yaşama gücü bakımından solüsyonlar arasında farklılık olmaması, kullanılan propolis 
solüsyonundaki aktif maddenin ya böyle bir etkisinin olmadığını veya mevcut çalışmada kullanılan propolisin yaşama gücü üzerine yararlı bir etkiye sahip olacak düzeyde olmadığını gösterir.

\section{Sonuçlar}

Hava kesesine in ovo propolis uygulamasının çıkış randımanını arttırmasına rağmen, civciv çıkış ağırlığında bir düşüşe neden olabileceği söylenebilir. Her iki denemede de tuz ve propolis enjeksiyonları arasinda in ovo enjeksiyon yeri ve bölgesi bakımından bir farklılık bulunmamasına rağmen, Deneme 1'de çıkış randımanının hava kesine yapılan enjeksiyonda amniyotik sıvıya göre daha yüksektir, dolayısıyla, enjeksiyon bölgesi olarak hava kesesi önerilebilir. Farklı yörelerden ve faunalardan elde edilmiş ve aynı zamanda farklı yöntemlerle hazırlanmış propolis solüsyonlarının etkinliği de araştırılmalıdır.

\section{Teșekkür}

$\mathrm{Bu}$ çalışma, Ondokuz Mayıs Üniversitesi, Ziraat Fakültesi Araştırma ve Uygulama Çiftliği'nin altyapı imkânları kullanılarak yürütülmüștür. Çalışmaya Fakülte idaresinin ve Hayvancılık Birimi personelinin vermiş oldukları destekler için teşekkür ederiz.

\section{Kaynaklar}

Anonymous, 2013. Statistical Package for the Social Sciences, IBM SPSS Statistics for Windows, Version 21.0. Armonk, NY: IBM Corp.

Arslan, S., Perçin, D., Silici, S., Koç, A.N., Er, Ö., 2010. Farklı çözücülerle hazırlanan propolis özütlerinin mutans streptokoklar üzerine in vitro antimikrobiyal etkisi. Sağllk Bilimleri Dergisi, 19(1): 68-73.

Bakyaraj, S., Bhanja, S.K., Majumdar, S., Dash, B., 2012. Modulation of post-hatch growth and immunity through in ovo supplemented nutrients in broiler chickens. Journal of the Science of Food and Agriculture, 92(2): 313-320.

Bhanja, S.K., Mandal, A.B., Goswami, T.K., 2004. Effect of in ovo injection of amino acids on growth, immune response, development of digestive organs and carcass yield of broiler. The Indian Journal of Animal Sciences, 39(3): 212-218.

Bhanja, S.K., Mandal, A.B., Agarwal, S.K., Majumdar, S., 2008. Effect of in ovo glucose injection on the post hatch-growth, digestive organ development and blood biochemical profiles in broiler chickens. The Indian Journal of Animal Sciences, 78(8): 869-872.

Bigot, K., Mignon Grasteau, S., Picard, M., Tesseraud, S., 2003. Effects of delayed feed intake on body, intestine and muscle development in neonate broilers. Poultry Science, 82(5): 781-788.
Boz, M.A., Sarıca, M., Yamak, U.S., 2014. The effect of oviposition time on hatching traits of different chicken genotypes. Europian Poultry Science, 78. DOI: 10.1399/eps.2014.11.

Christensen, V.L., Wineland, M.J., Fasenko, G.M., Donaldson, W.E., 2001. Egg storage effects on plasma glucose and supply and demand tissue glycogen concentrations of broiler embryos. Poultry Science, 80(12): 1729-1735.

Collin, A., Berri, C., Tesseraud, S., Rodon, F.E., SkibaCassy, S., Crochet, S., Duclos, M.J., Rideau, N., Tona, K., Buyse, J., Bruggeman, V., Decuypere, E., Picard, M., Yahav, S., 2007. Effects of thermal manipulation during early and late embryogenesis on thermotolerance and breast muscle characteristics in broiler chickens. Poultry Science, 86(5): 795-800.

De Oliveira, J.E., Uni, Z., Ferket, P.R., 2008. Important metabolic pathways in poultry embryos prior to hatch. World's Poultry Science Journal, 64(4): 488499.

Denli, M., Cankaya, S., Silici, S., Okan, F., Uluocak, A.N., 2005. Effect of dietary addition of Turkish propolis on the growth performance, carcass characteristics and serum variables of quail (Coturnix coturnix japonica). Asian-Australasian Journal of Animal Sciences, 18(6): 848-854.

Dimov, V., Ivanovska, N., Manolova, N., Bankova, V., Nikolov N., Popov, S., 1991. Immunomodulatory action of propolis. Influence on anti-infectious protection and macrophage function. Apidologie, 22(2): $155-162$

Dos Santos, T.T., Corzo, A., Kidd, M.T., McDaniel, C.D., Araújo, L.F., 2010. Influence of in ovo inoculation with various nutrients and egg size on broiler performance. The Journal of Applied Poultry Research, 19(1): 1-12.

Foye, O.T., Ferket, P.R., Uni, Z., 2007. The effects of in ovo feeding arginine, betahydroxy-beta-methylbutyrate, and protein on jejunal digestive and absorptive activity in embryonic and neonatal turkey poults. Poultry Science, 86(11): 2343-2349.

Gonzales, E., Cruz, C.P., Leandro, N.S.M., Stringhini, JH., Brito, A.B., 2013. In ovo supplementation of 25(OH)D3 to broiler embryos. Brazilian Journal of Poultry Science, 15(3): 169-286.

Leksrisompong, N., Romero-Sanchez, H., Plumstead, P.W., Brannan, K.E., Brake, J., 2007. Broiler incubation. 1. Effect of elevated temperature during late incubation on body weight and organs of chicks. Poultry Science, 86(12): 2685-2691.

Liu, P., Hu, Y., Grossmann, R., Zhao, R., 2012. In ovo leptin administration accelerates post-hatch muscle growth and changes myofibre characteristics, gene expression, and enzymes activity in broiler chickens. Journal of Animal Physiology and Animal Nutrition, 97(5): 887-895.

Moghaddam, A., Karimi, I., Borji, M., Bahadori, S., 2013. Effect of royal jelly in ovo injection on embryonic growth, hatchability, and gonadotropin levels of pullet breeder chicks. Theriogenology, 80(3): 193-198. 
Moghaddam, A., Borji, M., Komazini, D., 2014. Hatchability rate and embryonic growth of broiler chicks following in ovo injection royal jelly. British Poultry Science, 55(3): 391-397.

Moran, E.T., 2007. Nutrition of the developing embryo and hatchling. Poultry Science, 86(5): 1043-1049.

Ohta, Y., Tsushima, N., Koide, K., Kidd, M.T., Ishibashi, T., 1999. Effect of amino acid injection in broiler breeder eggs on embryonic growth and hatchability of chicks. Poultry Science, 78(11): 1493-1498.

Ohta, Y., Kidd, M.T., 2001. Optimum site for in ovo amino acid injection in broiler breeder eggs. Poultry Science, 80(10): 1425-1429.

Ohta, Y., Kidd, M.T., Ishibashi, T., 2001. Embryo growth and amino acid concentration profiles of broiler breeder eggs, embryos, and chicks after in ovo administration of amino acids. Poultry Science, 80(10): 1430-1436.

Sforcin, J.M., Fernandes, J.A., Lopes, C., Bankova, V., Funari, S.R.C., 2000. Seasonal effect on Brazilian propolis antibacterial activity. Journal of Ethnopharmacology, 73(1-2): 243-249.

Shalmany, S.K., Shivazard, M., 2006. The effect of diets propolis supplementation on ross broyler chicks performance. International Journal of Poultry Science, 5(1): 84-88.

Tewari, A.K., Maharana, B.R., 2011. Control of poultry coccidiosis: Changing trends. Journal of Parasitic Diseases, 35(1): 10-17.

Uni, Z., Smirnov, A., Sklan, D., 2002. Pre- and posthatch development of goblet cells in the broiler small intestine: effect of delayed access to feed. Poultry Science, 82(2): 320-327.

Uni, Z., Ferket, P.R., 2003. Enhancement of development of oviparous species by in ovo feding.
Publication number: US6592878 B2, North Carolina State University, Raleigh, NC; and Yissum Research Development Company of the Hebrew University of Jerusalem, Jerusalem (Israel), assignees.

Uni, Z., Tako, E., Gal, G.O., Sklan, D., 2003. Morphological, molecular, and functional changes in the chicken small intestine of the late-term embryo. Poultry Science, 82(11): 1747-1754.

Uni, Z., Ferket, P.R., 2004. Methods for early nutrition and their potential. World's Poultry Science Journal, 60(1): 101-111.

Uni, Z., Ferket, P.R., Tako, E., Kedar, O., 2005. In ovo feeding improves energy status of the late-term chicken embryos. Poultry Science, 84(5): 764-770.

Velazquez, C., Navarro, M., Acosta, A., Angulo, A., Dominguez, Z., Robles, R., Robles-Zepeda, R., Lugo, E., Goycoolea, F.M., Velazquez, E.F., Astiazaran, H., Hernandez, J., 2007. Antibacterial and free-radical scavenging activities of Sonoran propolis. Journal of Applied Microbiology, 103(5): 1747-1756.

Yamak, U.S., Sarıca, M., Boz, M.A., 2014. Comparing slow-growing chickens produced by two- and threeway crossing with commercial genotypes. 1. Growth and carcass traits. European Poultry Science (Archiv für Geflügelkunde), 78: 1-11.

Yamak, U.S., Sarıca, M., Boz, M.A., Önder, H., 2015. The effect of egg shell thickness on some hatching traits of broiler breeders. Kafkas Üniversitesi Veteriner Fakültesi Dergisi, 21(3): 421-424.

Zhai, W., Gerard, P.D., Pulikanti, R., Peebles, E.D., 2011. Effects of in ovo injection of carbohydrates on embryonic metabolism, hatchability, and subsequent somatic characteristics of broiler hatchlings. Poultry Science, 90(10): 2134-2143. 